\title{
Is External Debt Hampering Growth in the ECOWAS Region?
}

\author{
Felix Fofana N'Zue ${ }^{1,2}$ \\ ${ }^{1}$ Department of Economics and Management, Université Félix Houphouet Boigny Abidjan, Côte d'Ivoire \\ ${ }^{2}$ Economic Community of West African States (ECOWAS Commission), Department of Macroeconomic Policy \\ and Economic Research, Abuja, FCT, Nigeria \\ Correspondence: Felix Fofana N'Zué, Economic Community of West African States (ECOWAS Commission); \\ Department of Macroeconomic Policy and Economic Research, Abuja, FCT, Nigeria. Tel: 234-816-962-0518 / \\ 234-818-604-100 0. E-mail: felix.nzue@ gmail.com
}

Received: February 10, 2020

Accepted: February 29, 2020

Online Published: March 10, 2020

doi:10.5539/ijef.v12n4p54

URL: https://doi.org/10.5539/ijef.v12n4p54

\begin{abstract}
The paper aims to determine the impact of external debt on economic growth in the ECOWAS region. Panel data spanning from 1990 to 2016 is used and analyzed using panel CS-ARDL estimation approach. The results indicate cointegration among the variables. The paper found that external debt has a positive impact on economic performance up to a threshold. In the short run, the threshold stood at $45 \%$ and in the long run, it stood at $42.52 \%$. Beyond these points, additional external debt accumulation negatively affects the regional economic performance. Knowing that the level of the region's external debt-to-GDP ratio stood at $33.11 \%$ in 2018 (below the threshold), it appears that external debt has not yet hampered economic performance in the ECOWAS region. However, there is a need for caution given the fast rate of increase (25\% in six years) of external debt accumulation in the region.
\end{abstract}

Keywords: external debt, economic performance, nonlinearity, threshold

\section{Introduction}

It is well acknowledged that external debt can be harmful to economic growth if it gets too high. But how high is too high? $60 \%$ was indicated as a threshold beyond which growth will decline by $2 \%$ (Reinhart \& Rogoff, 2010). The debate still goes on as to the possible impact of public debt accumulation on economic growth. When debt is accumulated over long periods, it lowers the levels of economic activity and hurts economic performance by crowding out private investment and leading to higher long term interest rates and more aggressive future taxation (Chudik et al., 2018). This calls for concern especially in developing countries where it is argued that only sustained annual growth at around 7\% could ensure a developmental impact. Thus, developing countries cannot afford that their growth efforts be annihilated by excessive external debt.

In 2017, the International Monetary Fund (IMF) raised the alarm over the rising of public sector debt in African countries (IMF, 2017). Indeed, the IMF found that on average, the ratio of public debt to GDP increased by some $10 \%$ points since 2014 to an average of $48 \%$ of GDP in 2016 and expected to exceed 50\% in 2017. In the ECOWAS region, several countries have been identified with high risk of debt distress. They include Togo, Côte d'Ivoire, Niger, Benin, Cabo Verde, The Gambia, Ghana, Senegal and Sierra Leone (IMF, 2018; and AfDB, 2019). The West Africa Economic Outlook 2018 (AfDB, 2018) also underscore the rise of debt to GDP ratio of the region above $40 \%$. The debt to GDP ratio enable the assessment of a country or region's capacity to repay its debt. It therefore provides an indication of credit worthiness. It is thus important that it is monitored closely and the extent to which it is annihilating the growth efforts or not is investigated. In line with this, the Authorities of the ECOWAS Commission set a regional threshold at $70 \%$ as part of their agreed convergence criteria ${ }^{1}$ (ECOWAS, 2001). It is hoped that all the ECOWAS member countries will comply with this threshold among others and pave the way towards the envisaged single currency.

Debt as a result of borrowing, in itself, is not bad. Majority of developed countries entertain some level of indebtedness. It is rather the utilization of resources borrowed that matters. Indeed, the question is how well the resources are being utilized. Are these resources utilized for productive investment in which case the return on investment will enable debt repayment in the future? Or, are the borrowed monies used for final consumption expenditures? If debt monies are used for final consumption, the debt becomes a heavy burden that present and 
future generations will have to bear.

Knowing that excessive debt can lead to debt-overhang (Krugman, 1987) and crowding out (Diaz-Alejandro 1981) it is legitimate to wonder how debt to GDP ratio has impacted the economic performance of the ECOWAS countries overtime.

Hence, this paper seeks to determine the relationship between the ratio of total external debt stock (in current US\$) over gross domestic product (in current US\$) and economic growth in the ECOWAS region. The specific objectives are to: 1) determine the impact of external debt to GDP ratio variable on the region's economic performance; 2) determine if there is a threshold beyond which additional external debt will negatively affect the region's economic performance. The rest of the paper is structured as follows: section 2 presents stylized facts on the ECOWAS economy with special emphasis on the debt to GDP ratio then moves to a review of selected literature (section 3). Sections 4 and 5 present the data / methods of analysis and the empirical results. Section 6 concludes the papers.

\section{Stylized Facts}

Figure 1 below, depicts the trend of regional debt to GDP ratio from 1990 to 2016 . The overall trend is downward sloping although it was increasing in the early 90s. Regional debt to GDP ratio (hereafter debt) increased sharply from $138.54 \%$ in 1990 to $255.69 \%$ in 1994 which was an $84.56 \%$ increase in just five years. The year 1994 coincided with the devaluation of the CFA francs, the currency shared among eight of the fifteen ECOWAS countries. From 1994 going forward the debt indicator was downward sloping. This declining trend continued and it was only in 2007 that it reached a level below 100\%. It stood at $80.15 \%$. In 2016, the debt indicator stood at $32.17 \%$. This trend of the debt indicator is in contrast with the trends of per capita GDP and inflation. Indeed, these two indicators were both upward sloping throughout the period of analysis. Per capita GDP rose from US\$ 669.84 (constant 2010 US\$) in 1990 to US\$ 904.52 in 2016 which was an increase of 35\% over the period of analysis.

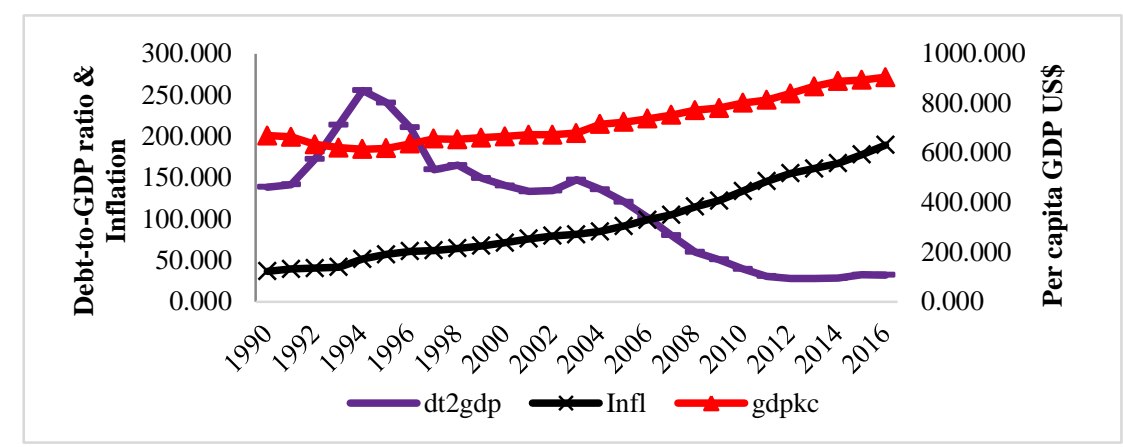

Figure 1. Trend of regional debt-to-GDP ratio, inflation in \% and per capita GDP in constant Us Dollar from 1990 to 2016

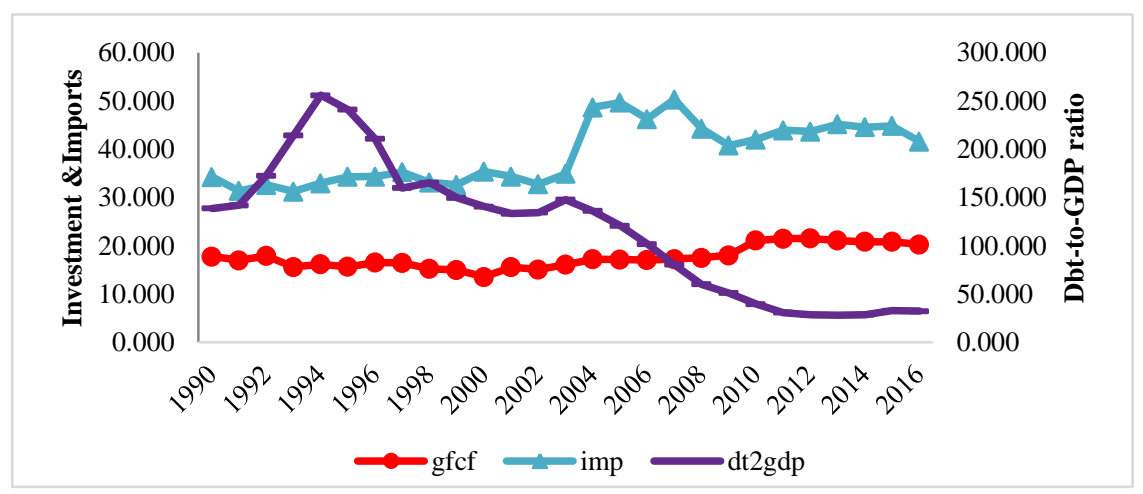

Figure 2. Trend of regional debt-to-GDP ratio, Investment and imports as \% of GDP from 1990 to 2016

In Figure 2, we looked at how imports of goods and services and investment at the regional level evolved. We observe that these two indicators were upward sloping contrary to the downward sloping trend of debt to GDP ratio. The regional imports stood at $34.27 \%$ in 1990 and increased to $41.55 \%$ in 2016 indicating some limitations 
in terms openness. The regional imports of goods and services reached its highest level in 2007 and stood at $50.26 \%$.

Looking at investment at the regional level, we observe that it has been very low. Indeed, it was below $20 \%$ from 1990 till 2010 where it rose to $21 \%$ and remained in the neighbourhood of $20 \%$ till 2016 . The highest investment rate stood at $21.48 \%$ of GDP and was achieved in 2012.

In Figure 3, the trends of life expectancy and population size are both upward sloping unlike the debt variable. Life expectancy at birth was 49 years in 1990 and rose sharply to 58 years in 2016 due to improvements in health services among others factors.

In addition to the above global trend, we looked at individual countries' recent trends of the debt variable and fiscal balance with the view to ascertaining their path towards the regional thresholds set at $70 \%$ and $3 \%$ for the debt and the fiscal deficit variables respectively.

In Benin republic, public debt stood at 56.1\% in 2018 from 49.7\% in 2016, a 12.9\% increase over just two years. This was a continuous increase over a period of five years. At the same time, the country's external debt which stood at $21.4 \%$ in 2016 rose to $26.5 \%$ in 2018 which is a $23.8 \%$ increase over a period of two years. External debt is expected to continue its rise in 2019 up to $27.3 \%$. The country's external debt is about $48.6 \%$ of total public debt. Although country's authorities are projecting a decline of total public debt starting from 2019, ensuring that it remains on that declining path will not be easy since it will require keeping the fiscal deficit ${ }^{2}$, which stood at $4.0 \%$ in 2018, below $3 \%$ of GDP to be in line with the ECOWAS criterion (IMF 2019a). The risk of debt distress is assessed as moderate.

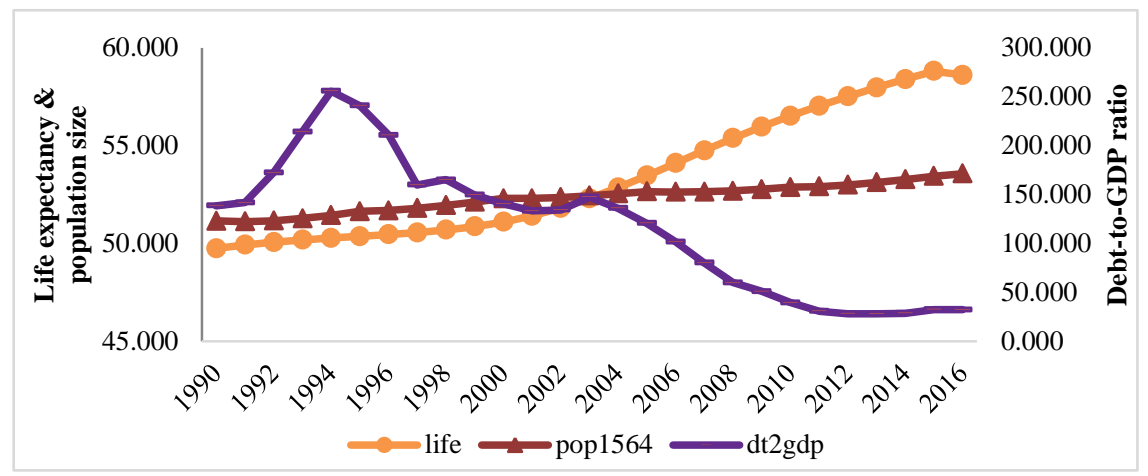

Figure 3. Trend of regional debt-to-GDP ratio (\% of GDP), life expectancy (in years) and population size (\% of total Population) from 1990 to 2016

In Burkina Faso, public debt stood at $42.5 \%$ in 2018 and is expected to stabilize around to $42 \%$ in 2019 (IMF, 2019 b). The country's external debt which was at $26.5 \%$ in 2016 has fallen to $23.8 \%$ in 2018 and it is about $56 \%$ of total public debt. The country's fiscal deficit which stood at $4.7 \%$ in 2018 is still above the ECOWAS threshold and is expected to be brought down to $3 \%$ in 2019.

In Cabo Verde, government debt is quite high. Indeed, it stood at $127.7 \%$ in 2018 and it is expected to slightly decrease to $125.3 \%$ in 2019. The country's external debt is also on the high side. It stood at $91.4 \%$ in 2016 and remained at that level in 2018. This is above the regional threshold and the external debt is above the level that Reinhart and Rogoff (2010) considered to be excessive. External debt is about $71.6 \%$ of the country's total debt. Despite this high level of government debt, the country's fiscal balance is within the regional threshold. Indeed, the fiscal deficit stood at $2.7 \%$ in 2018 and it is expected to be $2.3 \%$ in 2019 .

In Cote d'Ivoire, public debt is still on an upward sloping trend. It stood at 53.2 in 2018 up from the $48.4 \%$ registered in 2016 (IMF, 2019c). This is the highest level since the 2012 HIPC debt restructuring. 2019 is expected to be the turning point to reverse the upward trend of debt. External debt is also on the rise. Indeed, it moved from $27.7 \%$ of GDP in 2016 to $35.9 \%$ in 2018 which is a $29.6 \%$ increase over two years. The country's deficit stood at $4 \%$ above the regional threshold. It is expected to be brought back to the regional target of $3 \%$. The country's risk of debt distress is still classified as moderate.

The Gambia's total debt is also on the high side. Indeed, it is above $80 \%$ of GDP. In 2018 , it stood at $83.2 \%$ and expected to fall $78.7 \%$ in 2019 still above the regional threshold. The country's external debt stood at $40.9 \%$ in 
2016 and rose to $44.2 \%$ in 2018 . It is expected to fall to $42.3 \%$ in 2019 . It represents about $53 \%$ of government's debt. The country's fiscal balance is not encouraging. Indeed, the fiscal deficit has been in the neighborhood of $6 \%$ over the past three years i.e. 2016 to 2018. For 2018, it stood at 6.6\%. It is expected to drop to $0.2 \%$ in 2019 to comply with the regional target but this looks a bit unrealistic.

In Ghana, the second rebasing of GDP that took place in 2018 brought the Debt to GDP ratio which was at 71.8\% in 2017 above the regional threshold to $57.3 \%$. Government debt stood at $59.6 \%$ in 2018. External debt dropped slightly from $29.9 \%$ in 2016 to $27.9 \%$ in 2018. But it is expected to rise again in 2019 to $29.9 \%$ its level in 2016. The external debt is about $46.8 \%$ of total public debt. The country's fiscal balance is of concern. Indeed, the fiscal deficit stood at 7\% in 2018 and is expected to be at 5.5\% in 2019 thus missing the set regional threshold. The risk of debt distress remains high for the country (IMF, 2019d).

In Guinea, government's outstanding debt stood at $60 \%$ of GDP in 2005 and was reduced to $44.2 \%$ over the 2010-2015 period and was further brought down to 42 and $40 \%$ in 2016 and 2017 respectively. It stood at 38.7\% in 2018. External debt stood at 22.2\% in 2016 and is down to 21.1 in 2018. Despite this downward trend, both total debt and external debt are expected to climb to $46 \%$ and $30.7 \%$ respectively in 2019 (IMF, 2019e). The risk of overall debt distress is assessed as moderate (IMF, 2019). The country's deficit has remained below the ECOWAS threshold set at 3\%. Indeed, it stood at 2\% in 2018.

In Guinea Bissau, government debt has been alternating ups and downs. Indeed, it averaged $53.8 \%$ over the 2010-2015 period, rose to 57.9\% in 2016 and to 53.9\% in 2017. It stood in 2018 at 56.1\% and it is expected to fall back to $54.9 \%$ in 2019. External debt is on the rise. Indeed, from $20.8 \%$ in 2017, it stood at $22.7 \%$ and expected to rise at $23.4 \%$ in 2019 . The country's fiscal deficit is above the ECOWAS threshold. It stood at $5.6 \%$ in 2018 although the country authorities have vowed to bring it under control around $2.8 \%$ in 2019.

In Liberia, government debt is on the rise. Indeed, from $28.3 \%$ in 2016 it stood at $40.5 \%$ in 2018, which is a $43.1 \%$ increase in two years. The debt is expected to reach $46.7 \%$ in 2019 . The country's external debt followed similar trend. Indeed from $20.1 \%$ in 2016 it rose to $28.7 \%$ in 2018 (which is about $43 \%$ increase over two years) and represented $70.8 \%$ of total debt. At the same time Liberia's fiscal balance is not improving. Indeed, the country is running a fiscal deficit of $5.6 \%$ up from the $3.6 \%$ registered in 2016. This trend is worrisome because at this pace, the country will not meet the convergence criteria in 2019.

In Mali, government debt stood at $36.6 \%$ in 2018. This is a slight increase compared to the $35.4 \%$ registered in 2017 and it is not expected to increase much in 2019. The authorities are also trying to contain any rise in external debt. It stood at $23.3 \%$ in 2018 . On the fiscal balance side, although the fiscal deficit stood at $4.7 \%$ in 2018, it is expected to be brought down to $3 \%$ in 2019 the ECOWAS threshold.

Niger is one of the country that has experienced a high increase in government debt. Indeed, it move from $43.7 \%$ in 2016 to $55.1 \%$ in 2018 which is a $26 \%$ increase in two years. External debt also moved from $29.4 \%$ in 2016 to $36.2 \%$ in 2018 and it is expected to fall to $34.8 \%$ in 2019 . External debt represented 59.2\% of the country's total debt in 2018. The fiscal balance situation is not good either. Indeed, it moved from $6.1 \%$ in 2016 to $4.9 \%$ in 2018 . Despite this downward trend, the deficit is still above the Community's threshold.

In Nigeria, government debt is the lowest in the ECOWAS region. It stood at $28.4 \%$ in 2018 and is expected to reach $30 \%$ in 2019 . The country's external debt is also on the lower side. It stood at $8.8 \%$ in 2018 . The problem in Nigeria could be with the fiscal balance where it has been above the threshold for some years. It stood at $4.5 \%$ in 2018 and is expected to be at $5.1 \%$ in 2019 a worsening situation.

In Senegal, government debt is also on the rise. Indeed from $47.7 \%$ in 2016 it stood at $64.4 \%$ in 2018 which is a $35 \%$ increase over just two years. The country's external debt is on a similar trend. Indeed, it went from $31.2 \%$ in 2016 to $43.6 \%$ in 2018 , a $39.7 \%$ increase over two years and it is expected to reach $44.9 \%$ in 2019 . External debt represented about $67.7 \%$ of total debt in 2018. The fiscal deficit stood at $3.4 \%$ in 2018 and is expected to fall to $3 \%$ in 2019.

Sierra Leone is another ECOWAS country with rising government debt. Indeed, from 55.5\% in 2016, it jumped to $71.3 \%$ in 2018 which is a $28.5 \%$ increase in just two years. Similarly, external debt also rose from $36.7 \%$ in 2016 to $42.9 \%$ in 2018 and represented $60.2 \%$ of total debt in that year. The country's fiscal balance is also of concern given its high level. Indeed, it stood at 6.8\% in 2018 and is expected to be at $4.3 \%$ in 2019 missing the regional threshold.

In Togo, efforts are underway to bring government debt under control. Indeed, it has decreased from $81.1 \%$ in 2016 to $74.6 \%$ in 2018 which is an $8 \%$ reduction. Government debt is expected to be reduced further in 2019 down to the regional threshold. External debt on the other side is on the rise. It went from $19.2 \%$ in 2016 to $23.6 \%$ 
in 2018, an increase of $22.9 \%$ over two years and is expected to reach $25.9 \%$ in 2019 . On the fiscal balance, the country has also made efforts to bring the deficit within the acceptable limit of the regional threshold. It is expected to be below that threshold in 2019 at $1.5 \%$.

It results from the above that at the regional level government debt indicator is below the set regional threshold of $70 \%$. This is also true for individual member states with the exception of Cabo Verde, The Gambia, Sierra Leone and Togo. Although the level of government debt may appear not to be a concern in light of the threshold, it is the persistent and rapid accumulation of public debt that is of concern as argued by Chudik et al (2018). External debt is also on the rise at the regional level as well as at the individual country level with the exception of Mali, Ghana and Burkina Faso. Is there a regional threshold for external debt beyond which any additional borrowing will hamper the region's economic performance?

When we consider the regional fiscal balance, we observe that the regional deficit stood at $4.7 \%$ in 2018 from $4.3 \%$ in 2016. It is expected to remain at $4.7 \%$ in 2019 above the regional threshold. This is a matter of concern since the ECOWAS members states' economies were to converge towards the adopted threshold by 2019. As it stands, four of the fifteen countries of the ECOWAS region will not comply with this critical condition.

\section{Review of Selected Literature on the Debt and Growth nexus}

In this section, we provide a brief review of selected literature. Keeping in mind Reinhart and Rogoff (2010) arguments that the relationship between growth and debt depends on the levels of the debt to GDP ratio, we address successively the negative and positive impacts of external debt on economic growth as well as the possible nonlinear relationship.

\subsection{Both Negative and Positive Impacts of External Debt on Economic Growth}

The literature provides evidence for both negative and positive impacts of debt on economic growth. Scholars that found a negative relationship between external det to GDP ratio and per capita GDP include, Clements et al. (2003) in a paper on "External Debt, Public Investment, and Growth in Low-Income Countries", Malik et al. (2010) in a study on the relationship between external debt and economic growth in Pakistan, Babu et al. (2014) in a paper on the East Africa Community. In addition, Forgha et al. (2014), Lau and Kon (2014), Zouhaier and Mrad (2014), Ahmed et al. (2015), Kharusi and Ada (2018), Ciftcioglu and Sokhanvar (2018) and De Soyres et al. (2019) also found negative relationship between external debt to GDP ratio and per capita GDP.

Scholars who found positive relationship between external debt and growth include: Zaman and Arslan (2014) on a study on the role of external debt on economic growth in Pakistan; Kasidi and Said (2013) when they studied the Impact of External Debt on Economic Growth in Tanzania, and Uzun et al. (2012) in a study of the Impacts of External Debt on Economic Growth in Transition Economies.

\subsection{Nonlinear Relationship and Optimal Threshold Effect}

Many scholars believe that the relationship between external debt and economic growth is not linear. This argument has been tested empirically by Patillo et al. $(2002,2011)$ in their study on external debt and growth, Oleksandr (2003) in his study of post-Soviet countries, Baum et al. (2012) in their study of debt and growth in the Euro zone, Égert (2012) who interrogated whether the nonlinear effect of public debt and economic growth is a Myth or Reality; Greenidge et al. (2012) in their study on the threshold effects of sovereign debt in Carribean, Antonakakis (2014) in his study on the Role of (Non-) Sustainable Debt Thresholds., Irina and Ihnatov (2015) in their study on public debt and economic growth and Yifei (2017) when he or she conducted a Nonlinear Analysis of Economic Growth, Public Debt and Policy Tools.

\section{Data and Method of Analysis}

The data used for this study was obtained from the World Development Indicators 2018 (World Bank, 2018) $(\text { Note } 3)^{3}$. It ranged from 1990 to 2016 i.e. 26 years $(\boldsymbol{T})$ and 14 countries $(\boldsymbol{N})$ thus $\boldsymbol{T}>\boldsymbol{N}$. We investigated its time series characteristics. This entailed testing for unit roots. A problem that could emerge and needed to be resolved was the possible presence of cross sectional dependence. Indeed, these West African countries have vowed to harmonize their economic policies via what is known as the Macroeconomic Stability and Convergence Pact (ECOWAS, 2012). Moreover, these countries share borders, cultural and colonial heritage. Thus, observations could be influenced by some common considerations (common factors with heterogeneous factor loading) and hence the likely existence of cross sectional dependence. As argued by O'Connell (1998), the presence of cross sectional dependence (hereafter $C D$ ) may affect the finite sample behavior of the unit root test which subsequently leads to incorrect decision. Moreover, according to Philips and Sul (2003) the presence of a $C D$ may deteriorate the asymptotic distribution of the standard unit root test which is normally distributed. It is hence, trivial that ignoring $C D$ of errors can have serious consequences (Pesaran, 2013). We therefore started our 
analysis with an assessment of the existence of $C D$. Given the dimension of our panel data $(T>N)$ we followed Pesaran (2004) and used the following general panel data model:

$$
y_{i t}=\alpha_{i}+\beta_{i}^{\prime} x_{i t}+u_{i t}
$$

with $i=1,2, \ldots, N ; t=1,2, \ldots, T$. Where $i$ and $t$ are the cross section and time series dimensions respectively, $x_{i t}$ is a $k$ x $l$ vector of observed time varying regressors. The intercept and the slope coefficients $\left(\alpha_{i}\right.$ and $\left.\beta_{i}\right)$ are allowed to vary across $i$. For each $i, u_{i t} \sim \operatorname{IID}\left(0, \sigma_{i u}^{2}\right)$ for all $t$ although they can be cross-sectionally correlated (Pesaran 2004). The appropriate tests for cross-sectional dependence are proposed by Breusch and Pagan (1980), Pesaran (2004) and Pesaran et al. (2008). These tests are based, under the null hypothesis $\left(H_{0}\right)$ of no cross-section dependence i.e $\left(u_{i t}, u_{j t}\right)=0$, for all $i \neq j$, on a Lagrange Multiplier $(L M)$ statistics given by:

$$
C D_{L M}=T \sum_{i=1}^{N-1} \sum_{j=i+1}^{N} \hat{\rho}_{i j}^{2}
$$

Where $\hat{\rho}_{i j}$ is the sample estimate of the pairwise correlation of the residuals and is given by the following formulae:

$$
\hat{\rho}_{i j}=\hat{\rho}_{j i}=\frac{\sum_{t=1}^{T} \hat{u}_{i t} \hat{u}_{j t}}{\left(\sum_{t=1}^{T} \widehat{u}_{i t}^{2}\right)^{1 / 2}\left(\sum_{t=1}^{T} \hat{u}_{j t}^{2}\right)^{1 / 2}} \text {, and } \hat{u}_{i t} \text { is the OLS estimate of } u_{i t} \text { defined by }: \hat{u}_{i t}=y_{i t}-\hat{\alpha}_{i}-\hat{\beta}_{i}^{\prime} x_{i t} \text {. }
$$

The statistics in equation (2) i.e. $C D_{L M}$, is asymptotically distributed as chi-squared with $N(N-1) / 2$ degree of freedom. The assumption of the above test is that $N$ is constant and $T$ is large $(\rightarrow \infty)$. However, Pesaran (2004) proposed that when both $N$ and $T$ are large $(N \rightarrow \infty$ and $T \rightarrow \infty)$, the following test be used:

$$
C D_{L M 1}=\sqrt{\frac{1}{N(N-1)}}\left[\sum_{i=1}^{N-1} \sum_{j=i+1}^{N} T \hat{\rho}_{i j}\right] \sim \quad N(0,1)
$$

Pesaran et al (2008) proposed also a biased-adjusted version of the Breusch and Pagan (1980) CD test as follows:

$$
C D_{\text {LMadj }}=\frac{1}{C D_{L M}}\left[\frac{(T-k) \rho_{i j}^{2} \mu T_{i j}}{\sqrt{v_{i j}^{2}}}\right] \sim \quad N(0,1)
$$

In the absence of $C D$ the usual panel data unit root tests known as first generation panel unit root test are applied. These tests are the one developed by Levin et al. (2002), Breitung (2000), Im et al. (2003), Hadri (2000) and Maddala and $\mathrm{Wu}$ (1999). In the presence of $C D$ it is recommended to use second generation panel unit root tests. According to Hurlin and Mignon (2007), these tests relax the cross-sectional independence assumption by specifying the cross sectional dependencies. The various methods proposed could be grouped into two where in the first one, the cross-sectional dependencies are specified as a common factor model (Bai \& Ng, 2001, 2004; Phillips \& Sul, 2003; Moon \& Perron, 2004; Choi, 2002; and Pesaran, 2003). In the the second group restrictions are imposed on the covariance matrix of residuals. The approach in this second group raises some important technical problems (Hurlin \& Mignon, 2007) and hence is beyond the scope of this paper.

We consequently used the approach proposed in the first group and specifically that of Pesaran (2003, 2006 and 2007) i.e. the Cross-sectionally Augmented IPS (CIPS) test which has the correct size when compared to other existing panel unit root tests with CD (Pesaran et al., 2013). This test allows for heterogeneity in the autoregressive coefficient of the Dickey-Fuller regression and allows for the presence of a single unobserved common factor with heterogeneous factor loadings in the data.

Thus, following Chudik and Pesaran (2015) we considered the following empirical model:

$$
y_{i t}=\lambda_{i} y_{i t-1}+\beta_{i} x_{i t}+\mu_{i t}
$$

with

$$
\mu_{i t}=\gamma_{i}^{\prime} f_{t}+\varepsilon_{i t}
$$

Where $y_{i t}$ represent GDP per capita in country $i$ at time $t, x_{i t}$ is the set of control variables including the lagged of the dependent variable, $f_{t}$ is an unobserved common factor, $\gamma_{i}$ the heterogeneous factor loading and $\varepsilon_{i t} \sim \operatorname{IID}\left(0, \sigma_{\varepsilon}^{2}\right)$. Equation (5) can be estimated consistently by approximating the common factors with cross sectional averages as given below (Ditzen, 2019) :

$$
y_{i t}=\alpha_{i}+\lambda_{i} y_{i t-1}+\beta_{0 i} x_{i t}+\beta_{1 i} x_{i t-1}+\sum_{l=0}^{P_{T}} \delta_{i l}^{\prime} \bar{z}_{t-l}+\varepsilon_{i t}
$$

where $\bar{z}_{t}=\left(\bar{y}_{t-1}, \bar{x}_{t}\right)$ are the cross-sectional averages of the dependent and independent variables. This estimator is commonly called the Common Correlated Effects Mean Group Estimator (Ditzen, 2019). With this 
specification at hand we can estimate long run relationships. Ditzen suggested three approaches to estimate the long run relationships i.e. An error correction approach (ECM), a Cross-Section Distributed Lag (CS-DL) approach and a Cross-Section- $A R D L(C S-A R D L$ ) approach (Ditzen, 2019). For this paper we used the CS-ARDL approach which unlike the $C S$ - $D L$, estimates both short and long run relationships. The general representation of equation (5) as an $A R D L\left(p_{y} \cdot p_{x}\right)$ model is:

$$
y_{i t}=\alpha_{i}+\sum_{l=1}^{p_{y}} \lambda_{l i} y_{i t-l}+\sum_{l=0}^{p_{x}} \beta_{l i} x_{i t-l}+\mu_{i t}
$$

Equation (8) can be extended to accommodate cross sectional dependence as follows:

$$
y_{i t}=\alpha_{i}+\sum_{l=1}^{p_{y}} \lambda_{l i} y_{i t-l}+\sum_{l=0}^{p_{x}} \beta_{l i} x_{i t-l}+\sum_{l=0}^{p} \delta_{i l}^{\prime} \bar{v}_{t-l}+\varepsilon_{i t}
$$

With $\bar{v}_{t-l}=\left(\bar{y}_{i t-l}, \bar{x}_{i t-l}\right)$ and the long run coefficients and mean group estimates are obtained as:

$\hat{\theta}_{C S-A R D L, i}=\frac{\sum_{l=0}^{p_{x}} \widehat{\beta}_{l i}}{1-\sum_{l=1}^{p_{y}} \widehat{l}_{l i}}, \quad \hat{\bar{\theta}}_{M G}=\sum_{i=1}^{N} \hat{\theta}_{i}$. (Ditzen 2019 for more on this approach).

Taking stock of past work, we used a growth model augmented with selected variables of interest. These variables included: External debt to GDP ratio, in a linear and quadratic forms (The quadratic term in the specification enables the investigation of a turning point for External debt to GDP), inflation (Ininfl $l_{t}$ ), life expectancy (Inlife $e_{t}$ ), openness ( Inopen $_{t}$ ) and the proportion of the economically active population (population aged 15 to 64 years old) in the total population (Inpop 1564t). The final model to be estimated following Ditzen (2019) and assuming an $A R D L(1,0,0,0,0,0,0)^{4}$, is presented below:

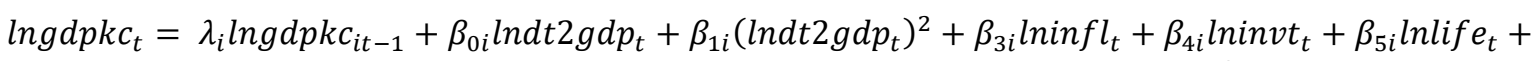

$$
\begin{aligned}
& \beta_{6 i} \text { lnopen }_{t}+\beta_{7 i} \operatorname{lnpop}_{1564_{t}}+\delta_{i 0} \operatorname{lngdpk}_{t-1}+\delta_{i 1}{\overline{\operatorname{lndt} 2 g d p_{t}}}+\delta_{i 2}\left({\overline{\operatorname{lndt} 2 g d p_{t}}}^{2}+\delta_{i 3} \overline{\operatorname{lninfl}}_{t}+\right. \\
& \delta_{i 4} \overline{\operatorname{lnlnvt}}_{t}+\delta_{i 5} \overline{\operatorname{lnllfe}}_{t}+\delta_{i 6} \overline{\operatorname{lnopen}}_{t}+\delta_{i 7} \overline{\operatorname{lnpop} 1564}_{t}+\epsilon_{t}
\end{aligned}
$$

Where: $\ln g d p k c_{t}$ is the natural logarithm of per capita GDP at current US\$; lndt2gdp is the natural logarithm of the ratio of External debt to GDP, measured in percentage; $\operatorname{lninfl} l_{t}$ is the natural logarithm of inflation proxied by the Consumer Price Index (CPI); Ininvt $t_{t}$ is also the natural logarithm of Gross Fixed Capital Formation (GFCF) used as a proxy for investment. It is measured as percentage of GDP; lnlife $e_{t}$ is the natural logarithm of life expectancy used as a proxy for human capital development; lnopen $_{t}$ is the natural logarithm of Imports of goods

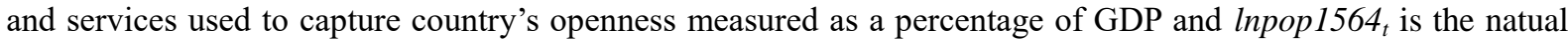
logarithm of the economically active population i.e. population aged between 15 to 64 years measured as a percentage of total population.

The specification in equation 10 enabled us to determine the threshold level of the External debt to GDP ratio. Which is the point where the impact of external debt on economic performance switches from positive to negative, ceteris paribus. By deriving equation 10 with respect to the variable lndt $2 g d p t$ we obtained:

$$
\frac{\partial \ln g d p k c_{t}}{\partial \ln d t 2 g d p_{t}}=\beta_{1}+2 \beta_{2} \ln d t 2 g d p_{t}^{*}=0
$$

With

$$
\frac{\partial^{2} \operatorname{lngdpkc_{t}}}{\partial^{2} \operatorname{lndt2gdp_{t}}}<0
$$

By solving equation (11), we obtained the optimum level of the external debt to GDP ratio as:

$$
\begin{gathered}
\ln d t 2 g d p_{t}^{*}=\frac{-\beta_{1}}{2 \beta_{2}} \\
d t 2 g d p^{*}=e^{\ln d t 2 g d p_{t}^{*}}
\end{gathered}
$$

\section{Empirical Results}

In Table 1, we observe that at the regional level, external debt to GDP ratio stood on average at $117.48 \%$ with a minimum of 3.93\% registered in Nigeria in 2012 and a maximum of 1,846.55\% registered in Liberia in 1995. Per capita GDP stood on average at US\$ 726.47 with a minimum of US\$115.79 registered in Liberia in 1995 and a maximum of US\$2,563 registered in Nigeria in 2014. Investment $\left(g f c f_{t}\right)$ stood on average at $17.55 \%$ which is quite low. The highest level of investment registered throughout the period in the region stood at $48.39 \%$ and was registered in Guinea Bissau. Life expectancy stood on average at 53 years and it ranged from a minimum 37 years in Sierra Leone to a maximum of 66 years in Senegal. The economically active population (population aged 15 to 64 years old) represented on average $52.32 \%$ of the total population. With a minimum of $47.219 \%$ in Niger and a maximum of $57.9 \%$ in Ghana. 
Table 1. Descriptive statistics of the variables of interest

\begin{tabular}{llllll}
\hline Variable & Mean & Std. Dev. & Min & Max & Obs. \\
\hline gdpkc $c_{t}$ & 726.479 & 436.681 & 115.794 & 2563.09 & 378 \\
$M_{t}$ & 39.048 & 24.031 & 10.492 & 236.392 & 378 \\
$X_{t}$ & 26.767 & 10.88 & 4.902 & 82.446 & 378 \\
$d t 2 g d p_{t}$ & 117.484 & 208.522 & 3.933 & 1846.55 & 378 \\
gfc $f_{t}$ & 17.551 & 7.306 & 0.293 & 48.397 & 378 \\
life & 53.369 & 5.702 & 35.701 & 66.661 & 378 \\
pop1564 $_{\text {infl }}$ & 52.323 & 2.005 & 47.219 & 57.935 & 378 \\
\hline
\end{tabular}

Source: Author's estimation.

In Table 2, we have pairwise correlations. External debt to GDP ratio and per capita GDP are negatively correlated (-0.264). We also observed that imports of goods and services is positively correlated with external-debt-to-GDP ratio unlike life expectancy which has a negative correlation with the variable of interest. These correlation results show no evidence of multicollinearities.

Table 2. Pairwise correlation analysis of variables of interest to check for possible multicollinearities

\begin{tabular}{|c|c|c|c|c|c|c|c|}
\hline & $g d p k c_{t}$ & $d t 2 g d p_{t}$ & $g f c f_{t}$ & $M_{t}$ & life $e_{t}$ & pop1564t & Infl $t_{t}$ \\
\hline$g d p k c_{t}$ & 1.000 & & & & & & \\
\hline$d t 2 g d p_{t}$ & -0.264 & 1.000 & & & & & \\
\hline$(0.000)$ & $(0.000)$ & & & & & & \\
\hline \multirow[t]{2}{*}{$g f c f_{t}$} & -0.094 & 0.021 & 1.000 & & & & \\
\hline & $(0.068)$ & $(0.690)$ & & & & & \\
\hline \multirow[t]{2}{*}{$M_{t}$} & -0.211 & 0.344 & 0.247 & 1.000 & & & \\
\hline & $(0.000)$ & $(0.000)$ & $(0.000)$ & & & & \\
\hline \multirow[t]{2}{*}{ life $_{t}$} & 0.0805 & -0.193 & 0.484 & 0.289 & 1.000 & & \\
\hline & (0.118) & $(0.000)$ & $(0.000)$ & $(0.000)$ & & & \\
\hline \multirow[t]{2}{*}{ pop1564t } & 0.384 & 0.052 & -0.125 & 0.266 & 0.222 & 1.000 & \\
\hline & $(0.000)$ & $(0.313)$ & $(0.015)$ & $(0.000)$ & $(0.000)$ & & \\
\hline \multirow[t]{2}{*}{ Infl $t_{t}$} & 0.011 & -0.082 & 0.272 & 0.352 & 0.524 & 0.283 & 1.000 \\
\hline & $(0.825)$ & $(0.109)$ & $(0.000)$ & $(0.000)$ & $(0.000)$ & $(0.000)$ & \\
\hline
\end{tabular}

Source: Author's estimation.

Table 3 presents the results of Pesaran's Cross-Section Dependence (CD) tests. The test results provide support for the existence of cross-sectional dependence. Indeed, for all the variables of interest, the null hypothesis of cross-sectional independence is rejected at the $1 \%$ probability level.

Table 3. Pesaran $C D$ test results for investigating cross sectional dependence in the data

\begin{tabular}{lccl}
\hline Variable & CD-test & p-value & Decision \\
\hline lngdpkc $t_{t}$ & 20.010 & 0.000 & Reject $\mathrm{H}_{0}$ \\
Indt $2 g d p_{t}$ & 34.920 & 0.000 & Reject $\mathrm{H}_{0}$ \\
${\text { Indt } 2 g d p s q_{t}}_{\text {lninvt }}$ & 35.320 & 0.000 & Reject $\mathrm{H}_{0}$ \\
lnopen $_{t}$ & 3.560 & 0.000 & Reject $\mathrm{H}_{0}$ \\
Inlife $_{t}$ & 6.520 & 0.000 & Reject $\mathrm{H}_{0}$ \\
lnpop1564 $_{t}$ & 42.790 & 0.000 & Reject $\mathrm{H}_{0}$ \\
lninfl $_{t}$ & 25.100 & 0.000 & Reject $\mathrm{H}_{0}$ \\
\hline
\end{tabular}

Note. The null hypothesis $\left(\mathrm{H}_{0}\right)$ is: Cross - Section Independence (Countries are independent from each other).

Source: Author's estimation.

In light these results, we used the second generation panel unit root tests. The results of these tests are presented in Table 4. The null hypothesis is that the series have a unit root i.e. I(1). We considered two specifications. One with trend and another one without trend. The results indicate that we have a mixture of $I(0)$ and $I(I)$ variables. Indeed, in both specifications, the $I(0)$ variables are lninvt $_{t}$ (the variable for investment) and Ininfl $_{t}$ (variable for 


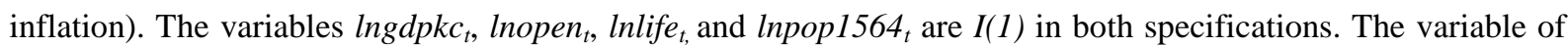

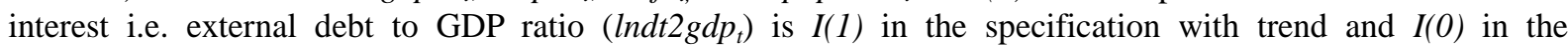
specification without trend. In view of the above panel unit root test results we estimated equation 10 . The estimation results are presented in Table 5 .

Table 4. Results of Panel Unit Root Tests using Pesaran CIPS test

\begin{tabular}{|c|c|c|c|c|c|c|c|c|}
\hline \multirow[t]{2}{*}{ Variables } & \multicolumn{4}{|c|}{ Specification without trend } & \multicolumn{4}{|c|}{ Specification with trend } \\
\hline & Lags & $\mathrm{Z}_{\mathrm{t}}$-bar & p-value & Remarks & Lags & $\mathrm{Z}_{\mathrm{t}}$-bar & $\mathrm{p}$-value & Remarks \\
\hline \multirow{2}{*}{$\operatorname{lngdpkc_{t}}$} & 0 & 0.589 & $(0.722)$ & $I(1)$ & 0 & 1.51 & $(0.935)$ & $I(1)$ \\
\hline & 1 & -0.005 & $(0.498)$ & $I(1)$ & 1 & 1.462 & $(0.928)$ & $I(1)$ \\
\hline \multirow{2}{*}{$\operatorname{lndt} 2 g d p_{t}$} & 0 & -2.927 & $(0.002)$ & $I(0)$ & 0 & -1.413 & $(0.079)$ & $I(1)$ \\
\hline & 1 & -2.613 & $(0.004)$ & $I(0)$ & 1 & -0.997 & $(0.159)$ & $I(1)$ \\
\hline \multirow{2}{*}{$\operatorname{lndt} 2 g d p s q_{t}$} & 0 & -2.407 & $(0.008)$ & $I(0)$ & 0 & -1.074 & $(0.141)$ & $I(1)$ \\
\hline & 1 & -2.035 & $(0.021)$ & $I(0)$ & 1 & -0.553 & $(0.290)$ & $I(1)$ \\
\hline \multirow{2}{*}{$\operatorname{lninvt}_{t}$} & 0 & -2.639 & $(0.004)$ & $I(0)$ & 0 & -4.403 & $(0.000)$ & $I(0)$ \\
\hline & 1 & -1.695 & $(0.045)$ & $I(0)$ & 1 & -3.094 & $(0.001)$ & $I(0)$ \\
\hline \multirow{2}{*}{ lnopen $_{t}$} & 0 & -3.283 & $(0.001)$ & $I(0)$ & 0 & -2.052 & $(0.020)$ & $I(0)$ \\
\hline & 1 & -1.123 & $(0.131)$ & $I(1)$ & 1 & 0.345 & $(0.635)$ & $I(1)$ \\
\hline \multirow{2}{*}{ lnlife $e_{t}$} & 0 & 0.042 & $(0.517)$ & $I(1)$ & 0 & 0.066 & $(0.526)$ & $I(1)$ \\
\hline & 1 & -12.188 & $(0.000)$ & $I(0)$ & 1 & -10.008 & $(0.000)$ & $I(0)$ \\
\hline \multirow{2}{*}{ lnpop $1564_{t}$} & 0 & 1.638 & (0.949) & $I(1)$ & 0 & 3.265 & (0.999) & $I(1)$ \\
\hline & 1 & -1.357 & $(0.087)$ & $I(1)$ & 1 & 2.052 & $(0.980)$ & $I(1)$ \\
\hline \multirow{2}{*}{$\operatorname{lninfl}_{t}$} & 0 & -4.864 & $(0.000)$ & $I(0)$ & 0 & -5.858 & $(0.000)$ & $I(0)$ \\
\hline & 1 & -1.914 & $(0.028)$ & $I(0)$ & 1 & -3.429 & $(0.000)$ & $I(0)$ \\
\hline
\end{tabular}

Note. The Null Hypothesis (H0) for the CIPS tests is that the series is $I(1)$. It assumes cross-sectional dependence is in form of a single unobserved common factor.

Source: Author's estimation.

We used the Cross-Section ARDL (CS-ARDL) proposed by Ditzen (2019) which enable us obtain both short and long run coefficients. The optimal lag selection process for the ARDL led us to settle for an ARDL(1,0,0,0,0,0,0). The results are presented in Table 5. Looking at the long run dynamics, we observe that the error correction term (ect) which is the speed of adjustment, is negative (-1.826) and significant. This is a clear indication of cointegration among the variables in the estimated model. The coefficient associated with external debt to GDP ratio is positive and significant in both short (0.396) and long run (0.240). The quadratic term of the variable of interest is negative and significant in also both short and long run, -0.052 and -0.032 respectively. This result is in support of a nonlinear relationship between external debt and economic growth. We can therefore compute, using equation 13, the optimal level of external debt to GDP ratio for the region. The calculated threshold in the short run is given by:

$\operatorname{lndt} 2 g d p_{t}^{*}=\frac{-0.396}{2(-0.052)}=3.807692$

$d t 2 g d p^{*}=e^{3.807692}=45.046$, thus, the turning point beyond which external debt to GDP ratio will hamper economic growth in the short run is $45 \%$. Let's see what happens in the long run. Using the results of the long run coefficients we obtain:

$\operatorname{lndt} 2 g d p_{t}^{*}=\frac{-0.24}{2(-0.032)}=3.75$

$d t 2 g d p^{*}=e^{3.75}=42.52$. Here, the turning point beyond which external debt to GDP ratio will negatively impact regional economic growth in the long run is $42.52 \%$.

In both short and long run the tipping point beyond which external debt to GDP ratio has a negative impact on economic growth is $45 \%$ for the short run and $42 \%$ for the long run. Over the period of analysis external debt to GDP ratio stood at $117.48 \%$ on average. With the HIPC initiative that benefited several ECOWAS member states, external debt burdens dropped significantly in the ECOWAS region but has started to rise again since 2013. Indeed, in 2013 it stood at $27.9 \%$ its lowest level. It rose to $33.11 \%$ in 2018 and is expected to reach $34.89 \%$ in 2019 corresponding to a $25 \%$ increase. Although, the current level is still below the turning point obtained from our estimations it is clear that the rate of external debt accumulation is impressive and needs to be addressed 
seriously before it is too late. It is important to also note that the results provide evidence of short and long run causality running from external debt to economic growth.

Table 5. Estimation results of the model assuming Common Correlated Effects (CCE) using CS-ARDL

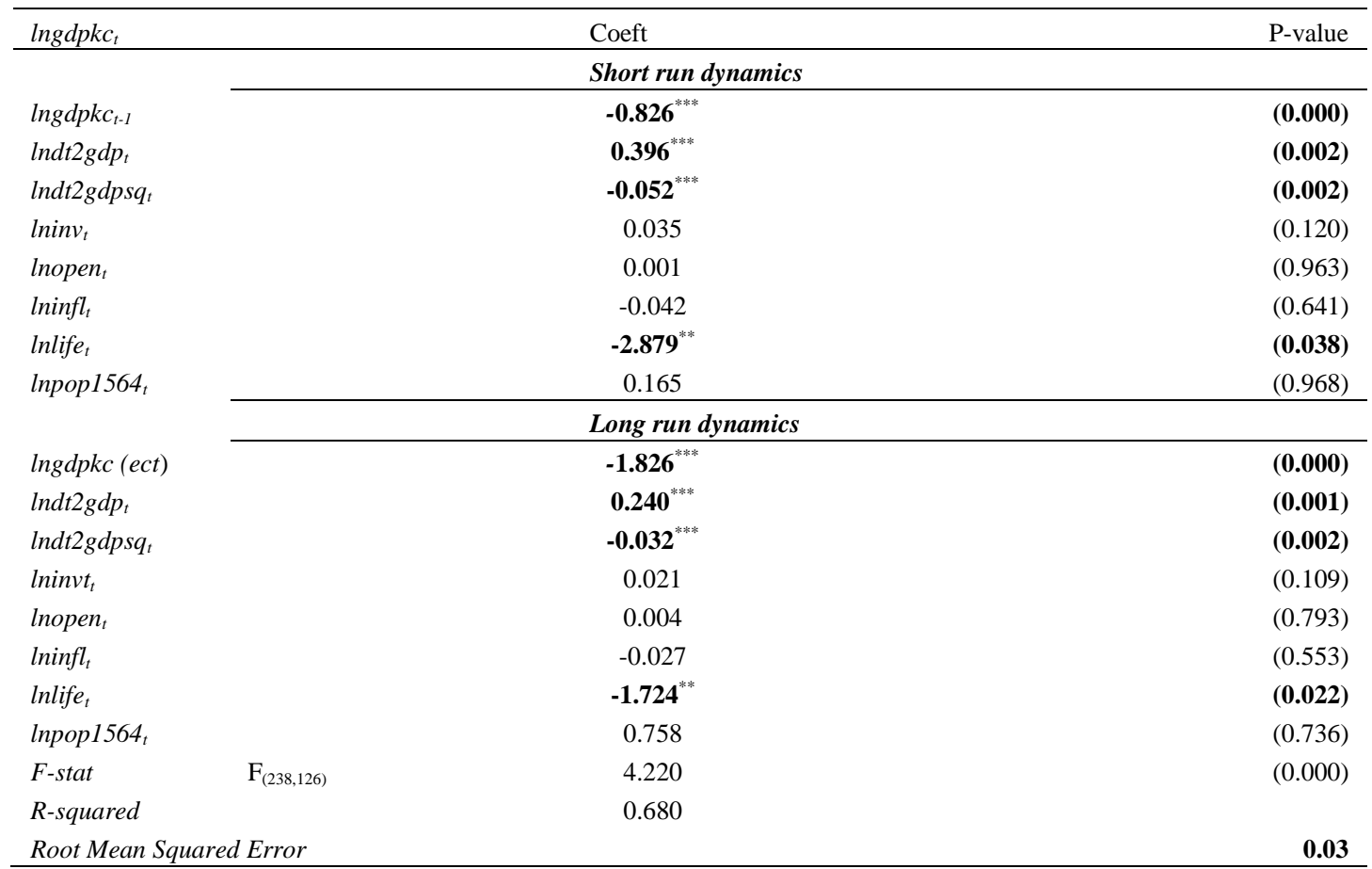

Source: Author's estimation.

Note. ${ }^{\text {SStata code: xtdcce2; * asterisks indicate significance level with }{ }^{*} \rightarrow 10 \%,{ }^{* *} \rightarrow 5 \% \text { and }}{ }^{* * *} \rightarrow 1 \%$ Discussions.

\section{Concluding Remarks}

The main objective of this paper was to contribute to the debate on the relationship between external debt to GDP ratio and economic growth in the ECOWAS region. We used panel data spanning from 1990 to 2016 to investigate the external debt and growth nexus. We tested whether the data exhibited cross sectional independence or not. The results showed evidence of cross-sectional dependence. We used second generation panel unit root tests to assess the time series characteristics of the data. We found a mixture of $I(0)$ and $I(1)$ variables. Thus, we used an $C S-A R D L$ approach to estimate the coefficients of equation 10 . We found that the variables were cointegrated and thus there is existence of a long run dynamic.

The empirical results provide support for the argument that external debt is good for growth (positive coefficient) up to a threshold level. Indeed, we found evidence of a nonlinear relationship between external debt to GDP ratio and Growth. More importantly, we found that in the short run the threshold stood at $45 \%$ and in the long run it stood at $42.52 \%$. These are the points beyond which additional external debt accumulation will negatively affect the regional economic performance. Given the current level of the region's external debt to GDP ratio (33.11\% in 2018), together with the positive and significant coefficient of the external debt to GDP ratio, external debt has not yet hampered economic growth in the ECOWAS region. However, there is need for caution given its fast rate of increase ( $25 \%$ in six years).

\section{Acknowledgments}

The author is greatful to an anonymous reviewer. Any shortcomings remain my own.

\section{References}

AfDB. (2018, 2019). The African Economic Outlook (AEO). African Development Bank.

Ahmed, A., Saeed, S. T., \& Saed, S. J. H. (2015). The Impact of External Debt on Economic Growth: Empirical Evidence from Iraq. International Journal of Science and Research, 4(8), 1506-1516.

Antonakakis, N. (2014). Sovereign Debt and Economic Growth Revisited: The Role of (Non-) Sustainable Debt Thresholds. WU. Department of Economics Working Paper No. 187 (October). 
Babu, J. O., Kyprop, S., Kalio, A. M., \& Gisore, M. (2014). External Debt and Economic Growth in the East African Community. African Journal of Business Management, 8(21), 1011-1018. https://doi.org/10.5897/AJBM

Bai, J., \& Ng, S. (2001). A PANIC Attack on Unit Roots and Cointegration. Mimeo, Boston College, Department of Economics. https://doi.org/10.2139/ssrn.294808

Bai, J., \& Ng, S. (2004). A PANIC Attack on Unit Roots and Cointegration. Econometrica, 72(4), 1127-1178. https://doi.org/10.1111/j.1468-0262.2004.00528.x

Baum, A., Checherita-Westphal, C., \& Rother, P. (2012). Debt and Growth: New Evidence for the Euro Area. European Central Bank Working Paper Series No 1450.

Breitung, J. (2000). The local power of some unit root tests for panel data, In B. Baltagi (Ed.), Nonstationary panels, panel cointegration, and dynamic panels, advances in econometrics (Vol. 15, 161-178). JAI: Amsterdam. https://doi.org/10.1016/S0731-9053(00)15006-6

Breusch, T. S., \& Pagan, A. R. (1980). The Lagrange Multiplier Test and its Application to Model Specifications in Econometrics. Review of Economic Studies, 47, 239-253. https://doi.org/10.2307/2297111

Choi, I. (2002). Combination Unit Root Tests for Cross-Sectionally Correlated Panels. Mimeo, Hong Kong University of Science and Technology.

Chudik, A., \& Pesaran, M. H. (2013). Large Panel Data Models with Cross-Sectional Depence: A Survey. Federal Reserve Bank of Dallas Working Paper No 153. https://doi.org/10.24149/gwp153

Chudik, A., Mohaddes, K., Pesaran, M. H., \& Rassi, M. (2015). Is there a Debt -threshold Effect on Output Growth? IMF Working Paper No WP/15/197. https://doi.org/10.5089/9781513513355.001

Chudik, A., Mohaddes, K., Pesaran, M. H., \& Rassi, M. (2018). Rising Public Debt to GDP can Harm Economic Growth. Economic Letter, 13(3), 1-4.

Chudik, A., \& Pesaran, M. H. (2015). Common correlated effects estimation of heterogeneous dynamic panel data models with weakly exogenous regressors. Journal of Econometrics, 188, 393-420. https://doi.org/10.1016/j.jeconom.2015.03.007

Chudik, A., Mohades, K., Pesaran, M. H., \& Raissi, M. (2013). Debt, Inflation and Growth: Robust Estimation of Long Run Effects in Dynamic Panel Data Models. CESifo Working Papers No 4508. https://doi.org/10.24149/gwp162

Çiftçioğlu, S., \& Sokhanvar, A. (2018). External Debt- Economic Growth Nexus in Selected CEE Countries. Romanian Journal of Economic Forecasting, 21(4), 85-100.

Clements, B., Bhattacharya, R., \& Nguyen, T. Q. (2003). External Debt, Public Investment, and Growth in Low-Income Countries. IMF Working Papers WP/03/249. https://doi.org/10.5089/9781451875904.001

De Soyres C., Picco, A. R., \& Sab, R. (2019). Debt Build-up in Frontier Low-Income Developing Countries (LIDCs) since 2012: Global or Country-specific Factors and Way Forward? IMF Working Paper WP/19/37. https://doi.org/10.5089/9781484396247.001

Diaz-Alejandro, C. (1981). Southern Cone Stabilization Plans. In W. Cline, \& S. Weintraub (Eds.), Economic Stabilization in Developing Countries. Washington, DC: The Brookings Institution.

Ditzen, J. (2018). Estimating dynamic common correlated effects in Stata. The Stata Journal, 18, 585-617. https://doi.org/10.1177/1536867X1801800306

Ditzen, J. (2019). Estimating long run effects in models with cross-sectional dependence using xtdcce2. Centre for Energy Economics Research and Policy (CEERP) Working Paper No. 7.

Eberhardt, M. (2012). Estimating panel time-series models with heterogeneous slopes. The Stata Journal, 12(1), 61-71. https://doi.org/10.1177/1536867X1201200105

ECOWAS. (2001). Decision A/DEC/17/12/01.

ECOWAS. (2012). Supplementary Act A/SA/4/06/12.

Égert, B. (2012). Public debt, Economic Growth and Nonlinear Effects: Myth or Reality? Economics Department Working Papers No. 993. https://doi.org/10.2139/ssrn.2302837

Forgha, N. G., Mbella, M. E., \& Ngangnchi, F. H. (2014). External Debt, Domestic Investment and Economic Growth in Cameroon: A system Estimation Approach. Journal of Economics Bibliography, 1(1), 3-19. 
Greenidge, K., Craigwell, R., Chrystol, T., \& Drakes, L. (2012). Threshold effects of sovereign debt: Evidence from the Carribean. IMF Working Paper no. 157, Washington, D.C.

Hadri, K. (2000). Testing for stationarity in heterogeneous panel data. Econometrics Journal, 3(2), 148-161. https://doi.org/10.1111/1368-423X.00043

Hurlin, C., \& Mignon, V. (2007). Second Generation Panel Unit Root Tests. Retrieved from https://halshs.archives-ouvertes.fr/halshs-00159842

Hurlin, C., \& Mignon, V. (2006). Une Synthèse des Tests de Racine Unitaire sur Données de Panel. Economie et Prévision, Minefi - Direction de la prévision, 169, 253-294. https://doi.org/10.3406/ecop.2005.7023

Im, K. S., Pesaran, M. H., \& Shin, Y. (2003). Testing for unit roots in heterogeneous panels. Journal of Econometrics, 115(1), 53-74. https://doi.org/10.1016/S0304-4076(03)00092-7

IMF. (2017). West African Economic and Monetary Union. Country report No. 17/99.

IMF. (2018). Regional economic outlook. Sub-Saharan Africa: capital flows and the future of work (October). International Monetary Fund, Publication Services P.O. Box 92780, Washington, DC 20090 (U.S.A.).

IMF. (2019a). Country Report No 19/203 (p. 4, 16, 17). Benin, International Monetary Fund, Washington, D.C. 20090.

IMF. (2019b). Country Report No 19/257 (p. 2, 5, 22). Burkina Faso, International Monetary Fund, Washington, D.C. 20090.

IMF. (2019c). Country Report No $19 / 197$ (p. 19). Cote d'Ivoire, International Monetary Fund, Washington, D.C. 20090. https://doi.org/10.5089/9781498323246.002

IMF. (2019d). Country Report No 19/97 (p. 29, 99). Ghana, International Monetary Fund, Washington, D.C. 20090.

IMF. (2019e). Regional Economic Outlook. Sub-Saharan Africa: Recovery amid Elevated Uncertainty (p. 59). International Monetary Fund, Washington, D.C. 20090 USA.

IMF. (2019f). Country Report No 19/82 (p. 17). Guinea, International Monetary Fund, Washington, D.C. 20431 USA. https://doi.org/10.5089/9781498303880.002

Irina, B., \& Iulian, I. (2015). Public debt and economic growth: A two-sided story. International Journal of Economic Sciences, IV(2), 24-39. https://doi.org/10.20472/ES.2015.4.2.003

Kasidi, F., \& Said, A. M. (2013). Impact of External Debt on Economic Growth: A Case Study of Tanzania. Advances in Management \& Applied Economics, 3(4), 59-82.

Kharusi, S. A., \& Ada, M. S. (2018). External Debt and Economic Growth: The Case of Emerging Economy, Journal of Economic Integration, 33(1), 1141-1157. https://doi.org/10.11130/jei.2018.33.1.1141

Krugman, P. (1987). Prospects for International Debt Reform, in International Financial Issues for the Developing Countries. Geneva: UNCTAD.

Lau, E., \& Thian-Ling, K. (2014). External Debt, Export and Growth in Asian Countries: 1988-2006. Journal of Applied Sciences, 14(18), 2170-76. https://doi.org/10.3923/jas.2014.2170.2176

Levin, A., Lin, C. F., \& Chu, C. S. J. (2002). Unit root tests in panel data: Asymptotic and finite-sample properties. Journal of Econometrics, 108(1), 1-24. https://doi.org/10.1016/S0304-4076(01)00098-7

Maddala, G. S., \& Wu, S. (1999). A comparative study of unit root tests with panel data and a new simple test. Oxford Bulletin of Economics and Statistics, 61, 631-652. https://doi.org/10.1111/1468-0084.61.s1.13

Malik, S., Muhammad, K. H., \& Muhammad, U. H. (2010). External Debt and Economic Growth: Empirical Evidence from Pakistan. International Research Journal of Finance and Economics, (44).

Moon, H. R., \& Perron, B. (2004a). Testing for a Unit Root in Panels with Dynamic Factors. Journal of Econometrics, 122, 81-126. https://doi.org/10.1016/j.jeconom.2003.10.020

O'Connell, P. (1998). The overvaluation of purchasing power parity. Journal of International Economics, 44(1), 1-19. https://doi.org/10.1016/S0022-1996(97)00017-2

Olesandr, D. (2003). Nonlinear Impact of External Debt on Economic Growth: The Case of Post Soviet Countries. Thesis for the degree of Master of Arts in Economics, National University of "Kyiv-Mohyla Academy", Ukraine. 
Patillo, C., Poirson, H., \& Ricci, L. A. (2002). External Debt and Growth. IMF Working Paper No 02/69. Washington D.C. International Monetary Fund. https://doi.org/10.5089/9781451849073.001

Patillo, C., Poirson, H., \& Ricci, L. A. (2011). External Debt and Growth. Review of Economics and Institutions, 2(3). https://doi.org/10.5202/rei.v2i3.45

Pesaran, H. M. (2003). A Simple Panel Unit Root Test in the Presence of Cross Section Dependence. Mimeo, University of Southern California. https://doi.org/10.2139/ssrn.457280

Pesaran, H. M. (2006). A Simple Panel Unit Root Test in the Presence of Cross Section Dependence. Mimeo, Cambridge University.

Pesaran, M. H. (2004). General diagnostic tests for cross section dependence in panels. Cambridge Working Papers in Economics No. 0435, University of Cambridge, Faculty of Economics.

Pesaran, M. H. (2007). A simple panel unit root test in the presence of cross section dependence. Journal of Applied Economics, 22(2), 265-312. https://doi.org/10.1002/jae.951

Pesaran, M. H., Ullah, A., \& Yamagata, T. (2008). A bias-adjusted LM test of error cross-section independence. Econometrics Journal, 11, 105-127. https://doi.org/10.1111/j.1368-423X.2007.00227.x

Pesaran, M. H., Smith, L. V., \& Yamagata, T. (2013). Panel Unit Root Tests in the Presence of a Multifactor Error structure. Journal of Econometrics, 175(2), 94-115. https://doi.org/10.1016/j.jeconom.2013.02.001

Philips, P. C. B., \& Sul, D. (2003). Dynamic panel estimation and homogeneity testing under cross section dependence. Econometrics Journal, 6(1), 217-259. https://doi.org/10.1111/1368-423X.00108

Reinhart, C. M., \& Kenneth, S. R. (2010). Growth in a Time of Debt, American Economic Review: Papers \& Proceedings, 100(May), 573-578. https://doi.org/10.1257/aer.100.2.573

Šimić, V., \& Vinko, M. (2012). Debts (Public and External) and Growth - Link or No Link? Croatian Operational Research Review (CRORR), 3, 201291.

Stiglitz, J. (2017). Austerity has strangled Britain. Only Labour will consign it to history. Retrieved from https://www.theguardian.com/commentisfree/2017/jun/07/austerity-britain-labour-neoliberalism-reagan-that cher

Uzun, A., Karakoy, C., Kabadayi, B., \& Emsen, O. S. (2012). The Impacts of External Debt on Economic Growth in Transition Economies. Chinese Business Review, 11(5), 491-499. https://doi.org/10.17265/1537-1506/2012.05.009

World Bank. (2019). Retrieved from http://datatopics.worldbank.org/world-development-indicators/

Yifei, C. (2017). Nonlinear Analysis of Economic Growth, Public Debt and Policy Tools. Asian Economic and Financial Review, 7(1), 99-108. https://doi.org/10.18488/journal.aefr/2017.7.1/102.1.99.108

Zaman, R., \& Arslan, M. (2014). The Role of External Debt on Economic Growth: Evidence from Pakistan Economy. Journal of Economics and Sustainable Development, 5(24), 140-147.

Zouhaier, H., \& Mrad, F. (2014). Debt and Economic Growth. International Journal of Economics and Financial Issues, 4(2), 440-448.

\section{Notes}

Note 1. Decision A/DEC/17/12/01 and modified in 2012 by an Additional Act A/SA.3/06/12).

Note 2. Commitment basis including grants.

Note 3. The data that support the findings of this study are available from the corresponding author, upon reasonable request.

Note 4. This ARDL structure was obtained using an optimal lag selection process.

\section{Copyrights}

Copyright for this article is retained by the author(s), with first publication rights granted to the journal.

This is an open-access article distributed under the terms and conditions of the Creative Commons Attribution license (http://creativecommons.org/licenses/by/4.0/). 